\title{
Removal of Emerging Pollutants in Horizontal Subsurface Flow and Vertical Flow Pilot-Scale Constructed Wetlands
}

\author{
Georgios D. Gikas ${ }^{1}{ }^{(D)}$, Vassiliki A. Papaevangelou ${ }^{1}$, Vassilios A. Tsihrintzis ${ }^{2, *}$, Maria Antonopoulou ${ }^{3}$ and \\ Ioannis K. Konstantinou 4,5
}

1 Laboratory of Ecological Engineering and Technology, Department of Environmental Engineering, School of Engineering, Democritus University of Thrace, 67100 Xanthi, Greece; ggkikas@env.duth.gr (G.D.G.); vpapaeva@env.duth.gr (V.A.P.)

2 Centre for the Assessment of Natural Hazards and Proactive Planning \& Laboratory of Reclamation Works and Water Resources Management, Department of Infrastructure and Rural Development, School of Rural, Surveying and Geoinformatics Engineering, National Technical University of Athens, Zografou, 15780 Athens, Greece

3 Department of Environmental Engineering, School of Engineering, University of Patras, 30100 Agrinio, Greece; mantonop@upatras.gr

4 Department of Chemistry, University of Ioannina, 45110 Ioannina, Greece; iokonst@uoi.gr

5 Institute of Environment and Sustainable Development, University Research Center of Ioannina (URCI), 45110 Ioannina, Greece

* Correspondence: tsihrin@otenet.gr or tsihrin@survey.ntua.gr

check for updates

Citation: Gikas, G.D.;

Papaevangelou, V.A.; Tsihrintzis, V.A.; Antonopoulou, M.; Konstantinou, I.K. Removal of Emerging Pollutants in Horizontal Subsurface Flow and Vertical Flow Pilot-Scale Constructed Wetlands. Processes 2021, 9, 2200. https://doi.org/10.3390/pr9122200

Academic Editor:

Avelino Núñez-Delgado

Received: 22 November 2021

Accepted: 5 December 2021

Published: 7 December 2021

Publisher's Note: MDPI stays neutral with regard to jurisdictional claims in published maps and institutional affiliations.

Copyright: (c) 2021 by the authors. Licensee MDPI, Basel, Switzerland. This article is an open access article distributed under the terms and conditions of the Creative Commons Attribution (CC BY) license (https:// creativecommons.org/licenses/by/ $4.0 /)$.

\begin{abstract}
We assessed constructed wetland (CW) performance in the removal of six emerging pollutants (EPs) from university campus wastewater. The EPs considered were: diethyl phthalate (DEP), di-isobutyl phthalate (DIBP), di-n-octyl phthalate (DNOP), bis(2-ehtylxexyl) phthalate (DEHP), tris(1-chloro-2-propyl) phosphate (TCPP) and caffeine (CAF). Six pilot-scale CWs, i.e., three horizontal subsurface flow (HSF) and three vertical flow (VF), with different design configurations were used: two types of plants and one unplanted for both the HSF and the VF, two hydraulic retention times (HRT) for the HSF, and two wastewater feeding strategies for the VF units. The results showed that the median removals in the three HSF-CWs ranged between 84.3 and 99.9\%, 79.0 and 95.7\%, 91.4 and $99.7 \%, 72.2$ and $81.0 \%, 99.1$ and $99.6 \%$, and 99.3 and $99.6 \%$ for DEP, DIBP, DNOP, DEHP, TCPP, and CAF, respectively. In the three VF-CWs, the median removal efficiencies range was 98.6-99.4\%, 63.6-98.0\%, 96.6-97.8\%, 73.6-94.5\%, 99.3-99.5\% and 94.4-96.3\% for DEP, DIBP, DNOP, DEHP, TCPP and CAF, respectively. The study indicates that biodegradation and adsorption onto substrate were the most prevalent removal routes of the target EPs in CWs.
\end{abstract}

Keywords: horizontal subsurface flow constructed wetlands; vertical flow constructed wetlands; phthalate esters; flame retardant (TCPP); caffeine

\section{Introduction}

The western modern lifestyle imposes great pressure on environmental compartments, which constitute the receivers of a great list of chemical compounds, known as emerging pollutants (EPs). Many of these substances are included in the EU Water Framework Directive priority list of 33 substances [1]; some of them are regulated [2,3], while others still remain unregulated.

The current study focused on three groups of EPs: phthalate esters (i.e., diethyl phthalate, DEP; di-isobutyl phthalate, DIBP; di-n-octyl phthalate, DNOP; bis(2-ehtylxexyl) phthalate, DEHP), a flame retardant (tris(1-chloro-2-propyl) phosphate, TCPP) and a stimulant (caffeine, CAF), due to their high production volume, widespread use and frequent residual presence in environmental compartments [4-7].

Phthalate esters (PEs) are vastly used in industrial, agricultural and domestic applications. They are mainly used as plasticizers in order to improve the durability, elasticity 
and flexibility of polymeric products [8-10]. PEs can also be applied in many consumer products, such as polyvinyl chloride (PVC) flooring, building materials, cosmetics, home furnishing, vinyl toys, food packaging and medicinal products [6,9]. These substances exhibit high environmental concern due to their production rates and ecotoxicological potential. Annually, more than $8 \times 10^{6}$ tons of phthalates are produced worldwide [8]. Certain PEs are currently regulated by the European Union [10] and DEHP is identified as a priority hazardous substance according to the EU Water Framework directive [1], and its use in cosmetics, medical devices and children's items (i.e., toys, care items) has been banned [3,9]. DEHP is the most widely used PE, characterized by low solubility and high sorption capacity to the solid phase, and as a result, it is the PE most often detected in the environment $[9,11]$. On the whole, due to their widespread application, PEs have frequently been detected in air, water, sediments, soil and food $[4,10,12,13]$.

Since some brominated flame retardants (BFRs) have been banned, phosphorus flame retardants (PFRs) (i.e., inorganic, organic, halogen containing BFRs) have been proposed as alternatives $[7,14]$. Organophosphorus flame retardants (OPFRs) are categorized as emerging contaminants due to their extensive use in various applications (e.g., in plastics, textiles and building materials) and their eventual presence in environmental matrices [7,15-17]. Their high environmental persistence and adverse effects on aquatic ecosystem and human health are well documented [14,16,18]. Among OPFRs, tris(1-chloro-2-propyl) phosphate (TCPP) attracts interest for several reasons: TCPP's high persistence in the environment, high release from finished products and TCPP heavy production and wide applications [7]. Therefore, TCPP constitutes an EU high production volume chemical listed in the EC fourth priority list [2,19] and is currently regulated [20]. According to previous studies, TCPP has been detected in wastewater effluents, surface and coastal waters, groundwater and drinking water [21-27].

Caffeine is a purine alkaloid and is normally found in drinks, such as coffee, tea and cocoa, but also constitutes a component of several prescription and non-prescription drugs $[5,28]$. It represents the most used tracer compound for wastewater pollution and has been frequently detected in WWTP effluents and final recipients [29-31]. One should bear in mind that, from a daily average consumption of caffeine of $131 \mathrm{mg} / \mathrm{d}$, only $3.9 \mathrm{mg}$ is excreted unchanged in the urine, while $127.1 \mathrm{mg}$ is metabolized [5].

Conventional wastewater treatment facilities are not designed to remove these emerging pollutants; thus, they can be partially removed or not removed at all, and therefore end up in final recipients $[12,13,17,26,30,32-35]$. Due to the widespread presence and persistence of these pollutants, several advanced treatment technologies have been applied, such as advanced oxidation technologies (Fenton or photocatalytic oxidation), ozonation or UV radiation. [17,36]. However, their application at the large-scale level is often cost-prohibitive [6]. Nowadays, constructed wetlands (CWs) provide a very popular and attractive alternative solution to the wastewater treatment technology, since the construction, operation and maintenance costs are very low [37-40]. CWs are used in treating various wastewaters, such as municipal [41-44], agricultural [45,46] and industrial wastewaters [47]. Over the last two decades, CWs have been used in the removal of several EPs [48-50]. However, although CWs have been found to be a successful technology for removing a number of EPs, including caffeine [28,29,31,51], there are fewer studies regarding PEs and TCPP [52-57]. The current study intends to focus on the fact that these compounds are often discharged into water bodies (coastal, surface and groundwater) as residual concentrations [32,49]. In addition, the investigation of the influence of several factors, including plant presence and type, seasonal variation, long term performance and hydraulic loading rate (HLR), is absent. Finally, there are no studies that compare and evaluate the simultaneous operation of two different types of CWs (VF and HSF) under the same climatic conditions. The current study will try to cover these gaps. 


\section{Materials and Methods}

\subsection{Wastewater Treatment System Facility Description and Wastewater Quality Monitoring}

In the present study, three horizontal subsurface flow (HSF), with code names HSF-R, HSF-C and HSF-Z, and three vertical flow (VF), with code names VF-R, VF-C and VF$\mathrm{Z}$, pilot-scale units were used. The units operated in the open space of the Laboratory of Ecological Engineering and Technology, Department of Environmental Engineering (location $41^{\circ} 08^{\prime} 47^{\prime \prime} \mathrm{N}, 24^{\circ} 55^{\prime} 09^{\prime \prime} \mathrm{E}$ ). The HSF-CW and VF-CW units were constructed in 2003 and 2007, respectively, and are considered mature CWs as they have operated continuously since then for the conduction of several experiments [58-63].

Each HSF-CW unit was a rectangular tank $3 \mathrm{~m}$ long, 0.75 wide and $1 \mathrm{~m}$ deep (Figure $1 \mathrm{a}$ ), filled with medium gravel $\left(D_{50}=15.0 \mathrm{~mm}\right.$, range $\left.4-25 \mathrm{~mm}\right)$ as a substrate at a thickness of $45 \mathrm{~cm}$. The plant type in the first unit was reed (Phragmites australis; HSF-R unit), in the second was cattail (Typha latifolia; HSF-C unit), and the third was used as a control and was kept unplanted (HSF-Z unit). In the HSF units, two hydraulic residence times (HRTs) of 14 and 20 days were applied with hydraulic loading rates ranging from 15.8 to $28.6 \mathrm{~L} /$ day. A full description of the HSF units is given by Akratos and Tsihrintzis [58].

(a)

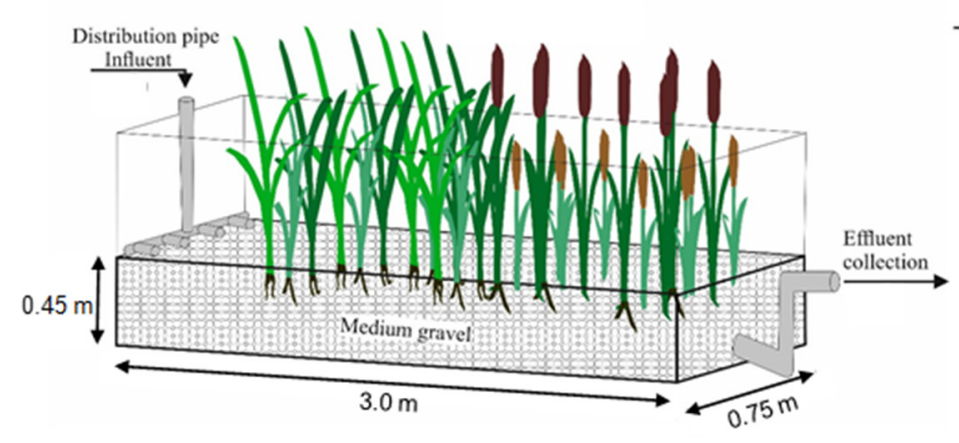

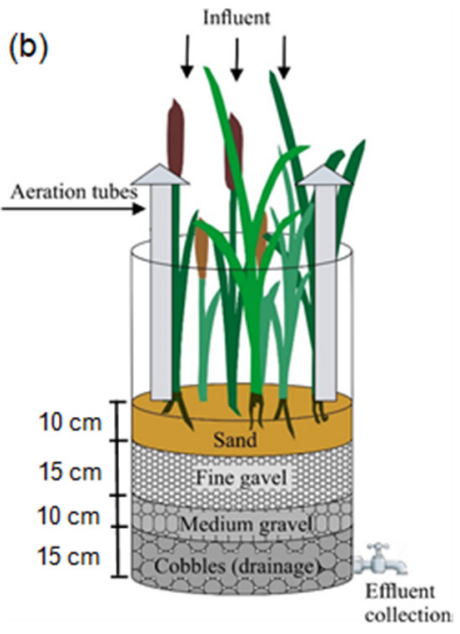

Figure 1. Experimental constructed wetlands: (a) horizontal subsurface flow constructed wetland; (b) vertical flow constructed wetland.

The VF-CWs pilot-scale units were cylindrical plastic tanks with a diameter of $0.82 \mathrm{~m}$ and a height of $1.5 \mathrm{~m}$. The porous media thickness was $50.0 \mathrm{~cm}$ and was placed in the following four layers (Figure 1b): (a) a drainage layer of cobbles, $15 \mathrm{~cm}$ thick (D50 = $90 \mathrm{~mm}$ ), placed at the bottom; (b) a $10 \mathrm{~cm}$ thick layer of medium gravel (D50 = 24.4 mm); (c) a $15 \mathrm{~cm}$ thick layer of fine gravel (D50 =6 mm); and finally, (d) a $10 \mathrm{~cm}$ thick top layer of sand $(\mathrm{D} 50=0.5 \mathrm{~mm})$. The drainage layer also contained aeration tubes, which were plastic pipes (50 $\mathrm{mm}$ in diameter) perforated only within the cobble drainage layer (Figure $1 \mathrm{~b}$ ). The first unit was planted with Phragmites australis (VF-R unit), the second with Typha latifolia (VF-C unit), and the third one was used as control unit (unplanted; VF-Z unit). A full description of the HSF units is given by Stefanakis and Tsihrintzis [59]. Two feeding strategies were applied as follows: in the first (strategy A), the loading (wet) and the resting (dry) period were two and four days, respectively, and in the second (strategy B), the wet and dry periods were two and six days, respectively; the respective hydraulic loading rates (HLR) were $0.209 \mathrm{~m} / \mathrm{d}$ (strategy A) and $0.283 \mathrm{~m} / \mathrm{d}$ (strategy B).

During the experimental period (about two years), all CW units (both HSF and VF) were supplied with municipal wastewater that originated from Democritus University Campus $[62,63]$. The influent wastewater was entered to the CW units every $8 \mathrm{~h}$ each day, while influent and effluent samples were collected in all seasons from each unit once every 15 days. 


\subsection{Chemicals and LC-MS Analysis}

For LC-MS analysis, methanol, $\mathrm{H}_{2} \mathrm{O}$ and isopropanol suitable for LC-MS applications from Fisher Scientific were used. Ammonium formate for mass spectrometry $\geq 99.0 \%$ was supplied by Sigma Aldrich (Steinheim, Germany). Di-2-ethylhexyl-phthalate (DEHP) with a purity of $99.9 \%$ was supplied by Supelco. The other phthalates (di-ethyl phthalate, di-isobutyl phthalate, di-n-octyl phthalate) were obtained from Dr. Ehrenstorfer (Germany). Analytical standards of TCPP (mixtures of isomers) and caffeine (> 99\%) were purchased from Sigma Aldrich (Steinheim, Germany). Table 1 lists the physicochemical characteristics and chemical structure of the study compounds [64].

Table 1. Physicochemical properties of substances under investigation [64].

\begin{tabular}{|c|c|c|c|c|c|}
\hline Substance & Formula & Chemical Structure & $\begin{array}{l}\text { Molecular Weight } \\
\text { (g/mol) }\end{array}$ & $\begin{array}{c}\text { Water } \\
\text { Solubility } \\
(\mathrm{mg} / \mathrm{L})\end{array}$ & $\log K_{\text {ow }}$ \\
\hline \multicolumn{6}{|c|}{ Phthalate Esters (PAEs) } \\
\hline $\begin{array}{l}\text { Diethyl phthalate } \\
\text { (DEP) }\end{array}$ & $\mathrm{C}_{12} \mathrm{H}_{14} \mathrm{O}_{4}$ & & 222.24 & 1100 & 2.47 \\
\hline $\begin{array}{l}\text { Di-isobutyl phthalate } \\
\text { (DIBP) }\end{array}$ & $\mathrm{C}_{16} \mathrm{H}_{22} \mathrm{O}_{4}$ & & 278.35 & 6.2 & 4.45 \\
\hline $\begin{array}{l}\text { Di-n-octyl phthalate } \\
\text { (DNOP) }\end{array}$ & $\mathrm{C}_{24} \mathrm{H}_{38} \mathrm{O}_{4}$ & & 390.56 & 0.022 & 8.06 \\
\hline $\begin{array}{l}\text { Bis(2-ethylhexyl) } \\
\text { phthalate (DEHP) }\end{array}$ & $\mathrm{C}_{24} \mathrm{H}_{38} \mathrm{O}_{4}$ & & 390.56 & 0.27 & 7.50 \\
\hline \multicolumn{6}{|c|}{ Flame retardant } \\
\hline $\begin{array}{l}\text { Tris (1-chloro-2-propyl) } \\
\text { phosphate (TCPP) }\end{array}$ & $\mathrm{C}_{9} \mathrm{H}_{18} \mathrm{Cl}_{3} \mathrm{O}_{4} \mathrm{P}$ & & 327.56 & 1600 & 2.59 \\
\hline \multicolumn{6}{|c|}{ Tracer (Stimulant) } \\
\hline Caffeine (CAF) & $\mathrm{C}_{8} \mathrm{H}_{10} \mathrm{~N}_{4} \mathrm{O}_{2}$ & & 194.19 & $22(\mathrm{~g} / \mathrm{L})$ & -0.07 \\
\hline
\end{tabular}


The micropollutant extraction from wastewaters and effluents as well as the LC-MSTOF analysis followed previously published methods and protocols [65]. High resolution accurate mass data, retention time, the adopted mode of ionization, and the limits of detection (LODs) and quantification (LOQs) of the compounds studied are given in Table 2.

Table 2. High resolution accurate mass data (exact mass, mass error $\Delta$ (ppm), retention time) and limits of detection (LOD) and quantification (LOQ) for target compounds using LC-MS/TOF.

\begin{tabular}{|c|c|c|c|c|c|c|}
\hline Compound & $\begin{array}{l}\text { Ionization } \\
\text { Mode }\end{array}$ & Measured m/z & $\begin{array}{c}\Delta \\
(\mathrm{ppm})\end{array}$ & $\begin{array}{c}\text { Rt } \\
(\mathrm{min})\end{array}$ & $\begin{array}{l}\text { LOD } \\
\text { (ng/L) }\end{array}$ & $\begin{array}{c}\text { LOQ } \\
(\mathrm{ng} / \mathrm{L})\end{array}$ \\
\hline Diethyl phthalate (DEP) & positive & 223.0961 & 1.9 & 8.9 & 1.2 & 4.0 \\
\hline Di-isobutyl phthalate (DIBP) & positive & 279.1597 & -2.3 & 11.1 & 2.5 & 8.3 \\
\hline Di-n-octyl phthalate (DNOP) & positive & 391.2833 & 2.5 & 12.3 & 1.8 & 6.0 \\
\hline Bis(2-ethylhexyl) phthalate (DEHP) & positive & 391.2837 & 1.5 & 13.8 & 2.8 & 9.3 \\
\hline $\begin{array}{c}\text { Tris (1-chloro-2-propyl) phosphate } \\
\text { (TCPP) }\end{array}$ & positive & 327.0071 & 3.1 & 9.7 & 1 & 3.3 \\
\hline Caffeine (CAF) & positive & 195.0880 & -1.9 & 5.6 & 3 & 10.0 \\
\hline
\end{tabular}

Rt: Retention time; LOD: Limit of detection; LOQ: Limit of quantification

\subsection{Statistical Analyses}

In the statistical analyses, which were conducted using the SPSS 25.0 statistical package software, the measured values of EPs below LOQ or LOD were set at half of LOQ or LOD. The non-parametric Kruskal-Wallis (KW) test and Mann-Whitney (MW) U-test were used, because the majority of the data failed to meet the assumption of normality and/or homogeneity. Differences in removal capacity among the three HSF-CW units and among the three VF-CW units were determined using the KW test. Where the KW test showed significant differences between units, the MW U-test was used to evaluate pairwise comparisons.

\section{Results and Discussion}

\subsection{Physicochemical Parameters in CWs}

Box-plots of the physicochemical parameters of the influent and effluents of the HSF and VF-CW units are presented in Figure 2. The mean wastewater temperature (T) at the inlet of the six pilot-scale units was $20.0{ }^{\circ} \mathrm{C}$, while at the outlet it ranged between 17.9 and $21.4^{\circ} \mathrm{C}$. The wastewater temperature range was between a minimum of $4.7^{\circ} \mathrm{C}$ and a maximum of $28.8^{\circ} \mathrm{C}$ (Figure 2a) and followed the seasonal variation, depending greatly on air temperature. The dissolved oxygen (DO) concentration in the six CWs also followed the seasonal variation, as it depends on the temperature with the highest values measured during the low temperature winter season. The mean DO concentrations in the effluent were greater than those in the influent in all CW units (Figure 2b). Higher mean DO concentrations were observed in the planted CWs (i.e., HSF-R, HSF-C, VF-R, VF-C) compared to the unplanted CWs (i.e., HSF-Z, VF-Z), indicating oxygen transfer to the rhizosphere by the plants. The mean $\mathrm{pH}$ values in the six pilot-scale units were in the alkaline range (Figure 2c), not greatly varying during the monitoring period, ranging between 7.0 and 7.9. The highest mean $\mathrm{pH}$ values were measured in the unplanted units (i.e., HSF-Z, VF-Z) compared to the planted ones, which showed lower values, as also observed by Kadlec and Wallace [66].

The mean electrical conductivity (EC) value of wastewater was $1299 \mu \mathrm{S} / \mathrm{cm}$; mean values at the outlet of the six pilot-scale CWs ranged between 1087 and $1691 \mu \mathrm{S} / \mathrm{cm}$. Higher effluent EC values were observed in the planted units compared to the unplanted units, something that is attributed to condensation due to evapotranspiration (Figure 2d). As also reported by Gikas et al. [67], higher EC values were observed in the planted CW units with Phragmites australis (i.e., HSF-R and VF-R) compared to those planted with cattails, which may be attributed to the action of the plant root system in releasing ions in the substrate and/or increased evapotranspiration losses. 

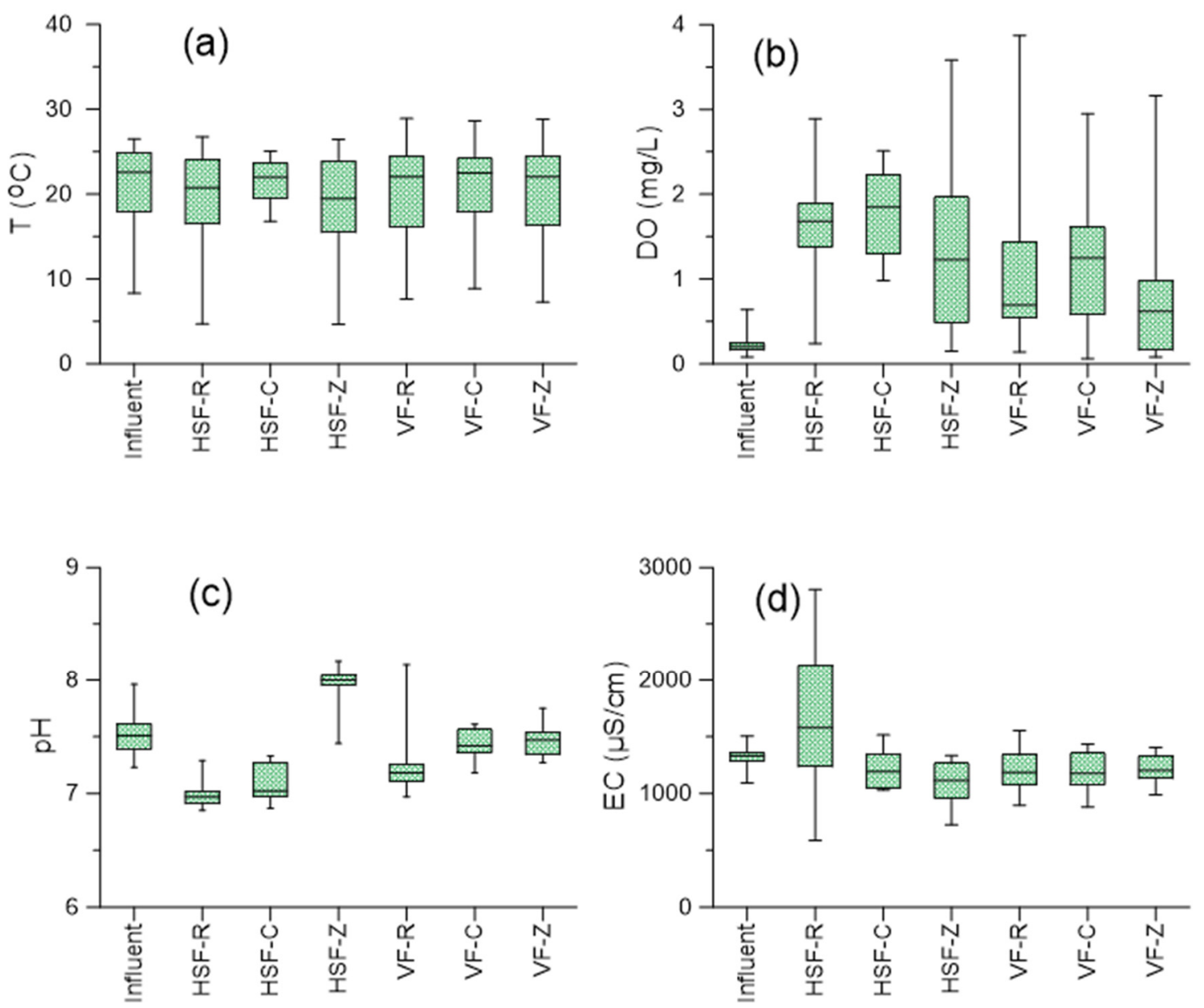

Figure 2. Box-whisker plots of the physicochemical parameters of the influent and effluents in the HSF and VF-CW units: (a) temperature; (b) dissolved oxygen; (c) $\mathrm{pH}$; (d) electrical conductivity. The whiskers at the end of each box indicate the minimum and maximum values. The box is defined by the lower and upper quartiles, and the line inside the box denotes the median value.

\subsection{Performance Statistics of HSF-CW Pilot-Scale Units}

Table 3 summarizes the mean, standard deviation (SD) and the min and max of influent and effluent EP concentrations in each pilot-scale CW. Figure 3 a presents the removal efficiencies of each HSF-CW unit, and Figure 4 presents the time series of the EP concentrations in the influent and effluent of the HSF-CW units during the study period. The DEP influent concentrations ranged from 0.066 to $3.044 \mu \mathrm{g} / \mathrm{L}$ (Table 3). The effluent mean concentration values for the HSF-R, HSF-C and HSF-Z units were 0.119, 0.004 and $0.076 \mu \mathrm{g} / \mathrm{L}$, respectively.

Table 3. Statistical parameters of influent and effluent concentrations.

\begin{tabular}{|c|c|c|c|c|c|c|c|c|c|}
\hline & \multirow{3}{*}{ Parameter } & \multicolumn{4}{|c|}{ HSF-CW } & \multicolumn{4}{|c|}{ VF-CW } \\
\hline & & \multirow{2}{*}{ Influent } & \multicolumn{3}{|c|}{ Effluent } & \multirow{2}{*}{ Influent } & \multicolumn{3}{|c|}{ Effluent } \\
\hline & & & HSF-R & HSF-C & HSF-Z & & VF-R & VF-C & VF-Z \\
\hline \multirow{5}{*}{$\begin{array}{c}\text { DEP } \\
(\mu \mathrm{g} / \mathrm{L})\end{array}$} & Mean & 1.086 & 0.119 & 0.004 & 0.076 & 1.085 & 0.058 & 0.025 & 0.012 \\
\hline & SD & 1.106 & 0.176 & 0.005 & 0.132 & 1.074 & 0.119 & 0.067 & 0.021 \\
\hline & $\min$ & 0.066 & BQL(10) & BQL(6) & BQL(5) & 0.091 & BQL(11) & BQL(11) & BQL(14) \\
\hline & $\max$ & 3.044 & 0.544 & 0.016 & 0.624 & 3.044 & 0.486 & 0.263 & 0.085 \\
\hline & $\mathrm{n}$ & 21 & 21 & 7 & 21 & 20 & 20 & 15 & 20 \\
\hline
\end{tabular}


Table 3. Cont

\begin{tabular}{|c|c|c|c|c|c|c|c|c|c|}
\hline & \multirow{3}{*}{ Parameter } & \multicolumn{4}{|c|}{ HSF-CW } & \multicolumn{4}{|c|}{ VF-CW } \\
\hline & & \multirow{2}{*}{ Influent } & \multicolumn{3}{|c|}{ Effluent } & \multirow{2}{*}{ Influent } & \multicolumn{3}{|c|}{ Effluent } \\
\hline & & & HSF-R & HSF-C & HSF-Z & & VF-R & VF-C & VF-Z \\
\hline \multirow{5}{*}{$\begin{array}{c}\text { DIBP } \\
(\mu \mathrm{g} / \mathrm{L})\end{array}$} & Mean & 1.121 & 0.299 & 0.288 & 0.147 & 0.710 & 0.289 & 0.048 & 0.106 \\
\hline & $\mathrm{SD}$ & 0.809 & 0.440 & 0.680 & 0.326 & 0.786 & 0.425 & 0.017 & 0.396 \\
\hline & $\min$ & 0.024 & 0.016 & 0.026 & 0.018 & 0.040 & 0.024 & BQL(1) & BQL(12) \\
\hline & $\max$ & 2.564 & 1.431 & 1.831 & 1.486 & 2.141 & 1.236 & 0.074 & 1.788 \\
\hline & $\mathrm{n}$ & 21 & 21 & 7 & 21 & 20 & 20 & 15 & 20 \\
\hline \multirow{5}{*}{$\begin{array}{l}\text { DNOP } \\
(\mu g / L)\end{array}$} & Mean & 0.425 & 0.051 & 0.017 & 0.024 & 0.412 & 0.045 & 0.016 & 0.015 \\
\hline & SD & 0.255 & 0.072 & 0.015 & 0.047 & 0.309 & 0.078 & 0.019 & 0.016 \\
\hline & $\min$ & 0.043 & BDL(5) & BDL(2) & BDL(13) & 0.024 & BDL(10) & BDL(7) & BDL(10) \\
\hline & $\max$ & 0.958 & 0.261 & 0.045 & 0.185 & 1.434 & 0.323 & 0.065 & 0.043 \\
\hline & $\mathrm{n}$ & 21 & 21 & 7 & 21 & 20 & 20 & 15 & 20 \\
\hline \multirow{5}{*}{$\begin{array}{l}\text { DEHP } \\
(\mu g / L)\end{array}$} & Mean & 1.597 & 0.663 & 0.461 & 0.643 & 1.334 & 0.431 & 0.060 & 0.181 \\
\hline & $\mathrm{SD}$ & 1.173 & 0.705 & 0.562 & 0.460 & 0.981 & 0.493 & 0.022 & 0.328 \\
\hline & $\min$ & 0.154 & 0.053 & 0.037 & 0.028 & 0.246 & 0.069 & 0.015 & 0.015 \\
\hline & $\max$ & 4.126 & 2.041 & 1.326 & 1.789 & 4.126 & 1.985 & 0.088 & 1.256 \\
\hline & $\mathrm{n}$ & 21 & 21 & 7 & 21 & 20 & 20 & 15 & 20 \\
\hline \multirow{5}{*}{$\begin{array}{l}\text { TCPP } \\
(\mu g / L)\end{array}$} & Mean & 0.115 & 0.005 & 0.001 & 0.001 & 0.103 & 0.001 & 0.001 & 0.001 \\
\hline & SD & 0.095 & 0.009 & 0.000 & 0.000 & 0.085 & 0.003 & 0.000 & 0.000 \\
\hline & $\min$ & 0.015 & BDL(17) & $\operatorname{BDL}(7)$ & BDL(21) & 0.015 & BDL(19) & BDL(15) & $\operatorname{BDL}(20)$ \\
\hline & $\max$ & 0.302 & 0.034 & BDL(7) & BDL(21) & 0.302 & 0.014 & BDL(15) & BDL(20) \\
\hline & $\mathrm{n}$ & 21 & 21 & 7 & 21 & 20 & 20 & 15 & 20 \\
\hline \multirow{5}{*}{$\begin{array}{c}\text { CAF } \\
(\mu \mathrm{g} / \mathrm{L})\end{array}$} & Mean & 1.372 & 0.042 & 0.010 & 0.076 & 1.319 & 0.014 & 0.011 & 0.006 \\
\hline & $\mathrm{SD}$ & 1.896 & 0.128 & 0.006 & 0.149 & 1.911 & 0.010 & 0.008 & 0.002 \\
\hline & $\min$ & BQL(6) & BQL(14) & BQL(4) & BQL(7) & BQL(5) & BQL(10) & BQL(9) & BQL(18) \\
\hline & $\max$ & 6.805 & 0.597 & 0.018 & 0.570 & 6.975 & 0.032 & 0.026 & 0.011 \\
\hline & $\mathrm{n}$ & 21 & 21 & 7 & 21 & 20 & 20 & 15 & 20 \\
\hline & & $\begin{array}{r}\text { BDL } \\
\text { BQL }= \\
\text { es in par }\end{array}$ & $\begin{array}{l}\text { low det } \\
\text { ow quan } \\
\text { esis indi }\end{array}$ & $\begin{array}{l}\text { limit: I } \\
\text { tion lim } \\
\text { he num }\end{array}$ & $\begin{array}{l}\mathrm{P}<1.8 \mathrm{n} \\
\mathrm{EP}<4.0 \\
\text { of sample }\end{array}$ & $\begin{array}{l}\mathrm{TCPP}< \\
\mathrm{CAF}< \\
\text { t were e }\end{array}$ & $\begin{array}{l}\mathrm{ng} / \mathrm{L} \\
\mathrm{ng} / \mathrm{L} \\
\mathrm{BDL} \text { or }\end{array}$ & & \\
\hline
\end{tabular}

The DEP effluent concentrations were below the LOQ at frequencies of $48 \%, 86 \%$ and $24 \%$ for units HSF-R, HSF-C and HSF-Z, respectively (Table 3; Figure 4a), while the respective mean removal efficiencies were $92.4 \%, 96.9 \%$ and $75.0 \%$ (Figure $3 a$ ). The statistical analysis (Table 4) indicated statistically significant differences in percent removal between the pilot-scale units $(p<0.05)$. The MW U-test showed that the DEP removal in the HSF-C unit was statistically significantly higher than that of the HSF-Z (unplanted) unit (Table $4 ; p<0.05$ ). The planted HSF unit presented higher removal efficacy than the unplanted unit, and it seems that the cattail contributes to the removal of DEP more than the reed. According to Verlicchi and Zambello [68], cattails have been found in some studies to be more effective in EP removal, while other studies found reeds to be more effective. Zheng et al. [69] reported 19.2\% DEP removal in a full-scale HSF-CW, which is lower than that of the present study. 

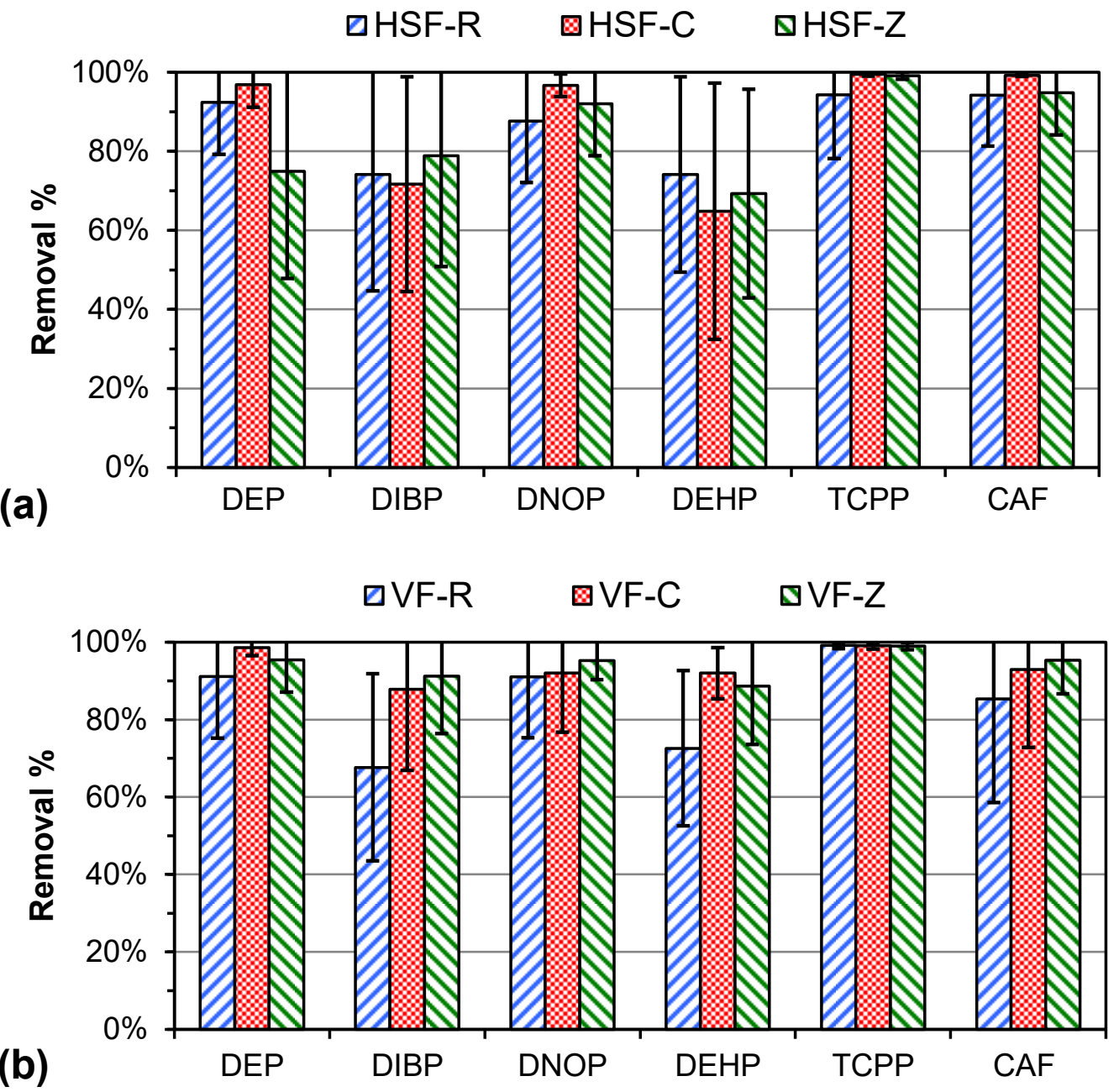

Figure 3. Mean removal values and standard deviation of EPs at pilot-scale units: (a) HSF-CW, (b) VF-CW.

The DIBP influent mean value for the HSF-CW units was $1.121 \mu \mathrm{g} / \mathrm{L}$ and the effluent mean values for the HSF-R, HSF-C and HSF-Z units were $0.299,0.288$ and $0.147 \mu \mathrm{g} / \mathrm{L}$, respectively. Lower effluent concentrations of DIBP were observed in most cases compared to influent values (Figure $4 \mathrm{~b}$ ). The mean removal efficiencies of DIBP were $74.1 \%, 71.7 \%$ and $78.9 \%$ for the HSF-R, HSF-C and HSF-Z units (Figure 3a), respectively, and there were no statistically significant differences $(p>0.05)$ in percent removal between the HSF-CW units (Table 4).

Zheng et al. [69] reported 19.4\% DIBP removal in a full-scale HSF-CW, which is lower than that of the present study, and the main removal mechanism was the adsorption on the substrate. On the other hand, Reyes-Contreras et al. [48] reported percent removals of about $30 \%, 20 \%$ and $50 \%$ in winter (February 2008) and $15 \%, 25 \%$ and $25 \%$ in summer (June-July 2009) for DEP, DIBP and DEHP, respectively, in an HSF-CW unit with $75 \mathrm{~m}^{2}$ surface in plan-view and HRT of 2.3 days. 

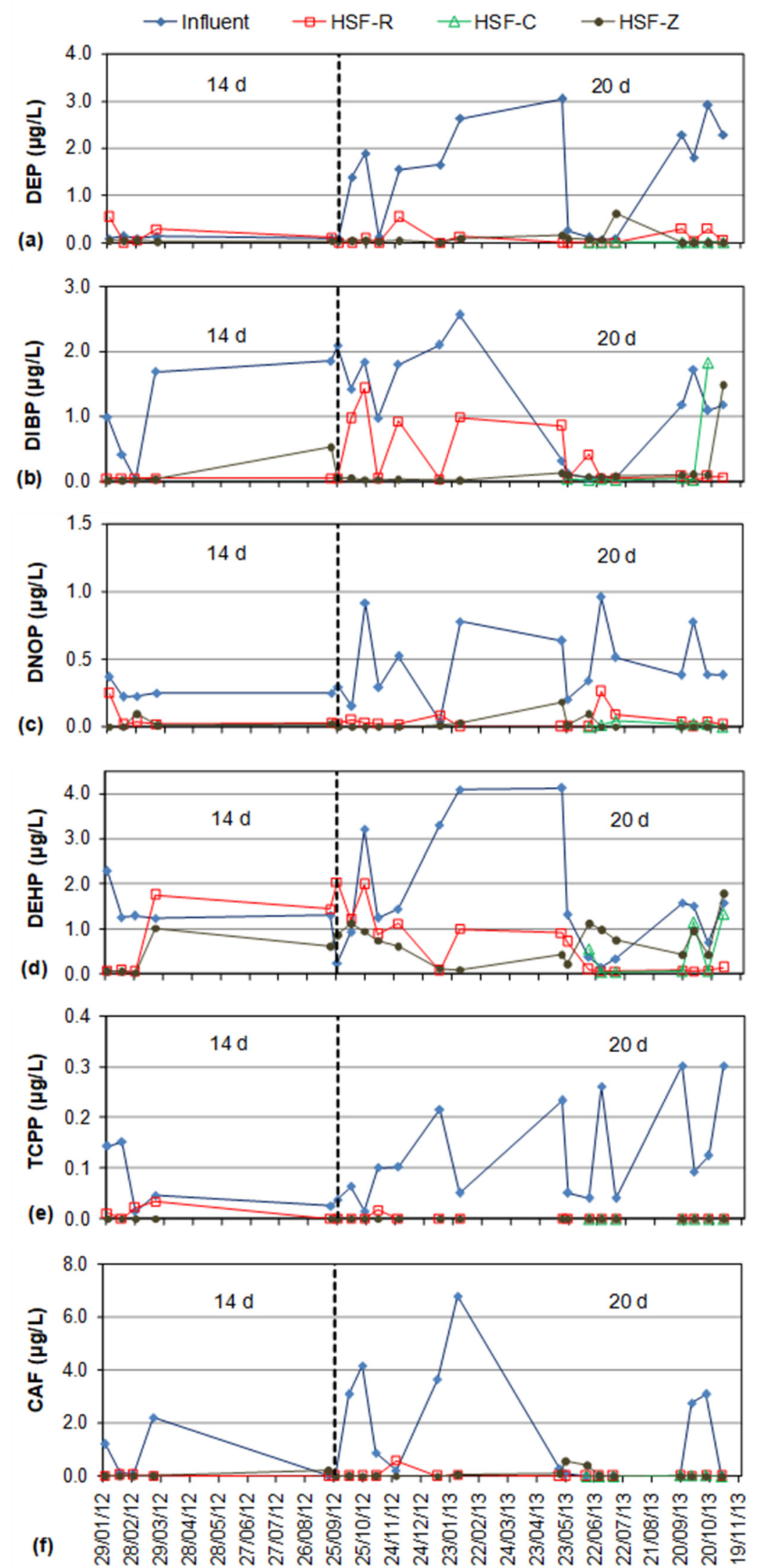

(f) คำ

Figure 4. Time series of influent and effluent concentration values in each HSF-CW unit (HRT indicated) for all pollutants: (a) DEP; (b) DIBP; (c) DNOP; (d) DEHP; (e) TCPP; (f) CAF. 
Table 4. Kruskal-Wallis and Mann-Whitney U-test results of removal EPs at CW units.

\begin{tabular}{|c|c|c|c|c|c|c|c|c|c|}
\hline \multicolumn{5}{|c|}{ HSF Pilot-Scale Units } & \multicolumn{5}{|c|}{ VF Pilot-Scale Units } \\
\hline \multirow[b]{2}{*}{ EPs } & \multicolumn{2}{|c|}{ Kruskal-Wallis Test } & \multicolumn{2}{|c|}{ Mann-Whitney U-Test } & \multirow[b]{2}{*}{ EPs } & \multicolumn{2}{|c|}{ Kruskal-Wallis Test } & \multicolumn{2}{|c|}{ Mann-Whitney U-Test } \\
\hline & $\begin{array}{c}\text { Test } \\
\text { Statistic }\end{array}$ & $p$ & $\begin{array}{c}\text { Compared } \\
\text { CWs }\end{array}$ & $p$ & & $\begin{array}{c}\text { Test } \\
\text { Statistic }\end{array}$ & $p$ & $\begin{array}{l}\text { Compared } \\
\text { CWs }\end{array}$ & $p$ \\
\hline \multirow[t]{3}{*}{ DEP } & 6.470 & 0.039 & $\begin{array}{l}\text { HSF-R, } \\
\text { HSF-C }\end{array}$ & 0.679 & DEP & 4.160 & 0.125 & & \\
\hline & & & $\begin{array}{l}\text { HSF-R, } \\
\text { HSF-Z }\end{array}$ & 0.328 & DIBP & 9.149 & 0.010 & VF-R, VF-C & 0.294 \\
\hline & & & $\begin{array}{l}\text { HSF-C, } \\
\text { HSF-Z }\end{array}$ & 0.048 & & & & VF-R, VF-Z & 0.008 \\
\hline DIBP & 1.335 & 0.513 & & & & & & VF-C, VF-Z & 0.905 \\
\hline DNOP & 3.428 & 0.180 & & & DNOP & 0.146 & 0.930 & & \\
\hline DEHP & 0.380 & 0.827 & & & DEHP & 13.112 & 0.001 & VF-R, VF-C & 0.010 \\
\hline ТСРP & 1.675 & 0.433 & & & & & & VF-R, VF-Z & 0.003 \\
\hline \multirow[t]{3}{*}{ CAF } & 0.168 & 0.919 & & & & & & VF-C, VF-Z & 0.971 \\
\hline & & & & & ТСРP & 0.072 & 0.965 & & \\
\hline & & & & & CAF & 1.627 & 0.443 & & \\
\hline
\end{tabular}

DNOP effluent concentrations were below LOD at frequencies $24 \%, 29 \%$ and $62 \%$ for HSF-R, HSF-C and HSF-Z units, respectively (Table 3; Figure 4c). They were also lower than influent values throughout the experimental period for all HSF-CW units. The influent mean concentration value for the HSF-CWs was $0.425 \mu \mathrm{g} / \mathrm{L}$, and the effluent mean concentration values for the HSF-R, HSF-C and HSF-Z units were $0.051,0.017$ and $0.024 \mu \mathrm{g} / \mathrm{L}$, respectively, while the respective removal capacities were $96.7 \%, 92.0 \%$ and $87.6 \%$ (Figure $3 a$ ). The statistical analysis (Table 4 ) indicated no statistically significant differences $(p>0.05)$ in the DNOP removal rates among the HSF-CWs.

The DEHP concentrations at the outlet were lower than the influent values for unit HSF-C, while the HSF-R and HSF-Z units showed relatively high outflow values, often exceeding those of the inflow at frequencies $23 \%$ and $40 \%$, respectively (Figure $4 \mathrm{~d}$ ). This resulted in low mean removal efficiencies for DEHP, which were $74.1 \%, 64.8 \%$ and $69.3 \%$ for the units HSF-R, HSF-C and HSF-Z (Figure 3a), respectively. Table 4 shows no statistically significant differences $(p>0.05)$ in percent removal between the HSF-CW units. The removal of DEHP in the present study was found to be higher than the removals reported in previous studies, e.g., 48.6\% DEHP removal in a full-scale HSF-CW [69]. Moreover, Xiaoyan et al. [6] reported removal of $31-45 \%$ and $21-34 \%$ for DNOP and DEHP, respectively, in pilotscale HSF-CW units-values lower than in the present study. Several studies conducted in activated sludge wastewater treatment plants (WWTP) reported that $74-81 \%$ of DEHP was eliminated due to microbial degradation [27]. However, several studies reported that DEHP is a persistent compound with a low biodegradation rate [70]. Finally, the accumulation of DEHP in the shoots of plant species like Typha was reported by Diepenheim et al. [71].

Regarding TCPP and CAF, the influent concentrations were higher than the effluent values throughout the experimental period for all HSF-CWs. The TCPP concentration was below LOD at frequencies higher than $81 \%$ (Table 3; Figure 4e), and the CAF concentration was below LOQ at frequencies $67 \%, 57 \%$ and $33 \%$ for the HSF-R, HSF-C and HSF-Z units, respectively (Table 3; Figure $4 \mathrm{f}$ ). The mean removal efficiencies of TCPP were $94.3 \%, 99.4 \%$ and $99.1 \%$, and of CAF $94.2 \%, 99.1 \%$ and $94.8 \%$ for the HSF-R, HSF-C and HSF-Z units, respectively (Figure 3a). Table 4 (KW test) shows no statistically significant differences in percent removal $(p>0.05)$ between the HSF-CW units for both TCPP and CAF. The results of laboratory degradation experiments conducted by Regnery and Püttmann [15] showed that TCPP is resistant to degradation by sunlight. In addition, according to Iqbal et al. [72], TCPP has low biodegradability, which makes it more abundant in river water. On the other hand, Reemtsma et al. [18] reported that TCPP sorption on activated sludge was the major removal process in a WWTP. Furthermore, according to Qin et al. [73], the absorption and 
accumulation of TCPP by hydrophytes contributes to TCPP removal in CWs. In addition, Brunsch et al. [74] reported that biodegradation, sorption on substrate and/or plant uptake likely occurs in CWs. Consequently, biodegradation, adsorption on the substrate and plant uptake are the main mechanisms of TCPP removal in CWs. The mean removal efficiencies of CAF were high (94.2-99.1\%) in the HSF-CWs of the present study and are in agreement with previous studies, which showed that CAF is an easily removable EP. Chen et al. [31] reported CAF removal of 93-99\% in full-scale HSF-CWs, and other studies also reported high removal efficiencies of CAF (65-98\%) in HSF-CWs [29,49].

According to the experimental setup, the HSF-R and HSF-Z units operated at HRTs of 14 and 20 days, while the HSF-C unit only operated at an HRT of 20 days (Figure 4). The mean removal efficiencies in HSF-CW units for HRTs of 14 and 20 days are presented in Table 5. The MW U-test (Table 6) indicated a statistically significant difference $(p<0.05)$ between the HRT of 14 days and 20 days only for DEHP and CAF in the HSF-R unit, and for DNOP in the HSF-Z unit. The LogK $\mathrm{K}_{\mathrm{ow}}$ of DNOP and DEHP are 8.06 and 7.50, respectively (Table 1), and are characterized as hydrophobic compounds. Other studies have reported that mainly for hydrophobic organic compounds there is positive correlation between HRT and the removal efficiency [68,75]. Zhang et al. [56] reported a linear correlation between CAF removal and HRT. The results of the present study indicate that an HRT of 14 days may be adequate for target compound removal.

Table 5. Removal efficiencies (\%) observed in the constructed wetlands.

\begin{tabular}{|c|c|c|c|c|c|c|c|c|c|c|c|c|c|}
\hline \multirow{3}{*}{ EPs } & \multicolumn{6}{|c|}{ HSF Pilot-Scale Units } & \multicolumn{7}{|c|}{ VF Pilot-Scale Units } \\
\hline & \multirow{2}{*}{$\begin{array}{l}\text { Overall } \\
\text { Removal }\end{array}$} & \multicolumn{2}{|c|}{ HRT 14d } & \multicolumn{3}{|c|}{ HRT 20d } & \multirow{2}{*}{$\begin{array}{l}\text { Overall } \\
\text { Removal }\end{array}$} & \multicolumn{3}{|c|}{ Feeding Strategy A } & \multicolumn{3}{|c|}{ Feeding Strategy B } \\
\hline & & HSF-R & HSF-Z & HSF-R & HSF-C & HSF-Z & & VF-R & VF-C & VF-Z & VF-R & VF-C & VF-Z \\
\hline DEP & 85.4 & 88.1 & 67.1 & 94.1 & 96.9 & 80.2 & 94.6 & 91.9 & 98.8 & 92.6 & 90.0 & 98.5 & 99.5 \\
\hline DIBP & 76.7 & 90.9 & 87.5 & 63.4 & 71.7 & 75.8 & 81.8 & 63.7 & 80.8 & 86.3 & 74.3 & 93.6 & 96.8 \\
\hline DNOP & 90.9 & 82.5 & 87.6 & 90.4 & 96.7 & 94.8 & 92.9 & 88.3 & 87.2 & 94.4 & 94.7 & 96.3 & 96.5 \\
\hline DEHP & 70.7 & 92.1 & 79.1 & 66.6 & 64.8 & 60.7 & 84.0 & 75.1 & 93.8 & 85.7 & 68.7 & 90.4 & 93.3 \\
\hline ТСРP & 98.2 & 94.7 & 98.8 & 97.9 & 99.4 & 99.2 & 99.0 & 99.1 & 99.0 & 98.9 & 99.1 & 99.1 & 99.1 \\
\hline CAF & 95.2 & 86.4 & 93.5 & 99.2 & 99.1 & 95.6 & 91.2 & 76.5 & 86.3 & 92.6 & 99.2 & 98.7 & 99.3 \\
\hline
\end{tabular}

Table 6. Mann-Whitney U-test results of comparison for HRT and feeding strategy.

\begin{tabular}{|c|c|c|c|c|c|}
\hline \multicolumn{3}{|c|}{ HSF Pilot-Scale Units } & \multicolumn{3}{|c|}{ VF Pilot-Scale Units } \\
\hline \multicolumn{3}{|c|}{ HRT Comparison: $14 d$ and $20 d$} & \multicolumn{3}{|c|}{ Feeding Strategy Comparison: A and B } \\
\hline EPs & CW Unit & $p$ & EPs & CW Unit & $p$ \\
\hline \multirow[t]{2}{*}{ DEP } & HSF-R & 0.882 & DEP & VF-R & 0.642 \\
\hline & HSF-Z & 0.162 & & VF-C & 0.459 \\
\hline \multirow[t]{2}{*}{ DIBP } & HSF-R & 0.052 & & VF-Z & 0.012 \\
\hline & HSF-Z & 0.183 & DIBP & VF-R & 0.386 \\
\hline \multirow[t]{2}{*}{ DNOP } & HSF-R & 0.361 & & VF-C & 0.855 \\
\hline & HSF-Z & 0.040 & & VF-Z & 0.500 \\
\hline \multirow[t]{2}{*}{ DEHP } & HSF-R & 0.020 & DNOP & VF-R & 0.115 \\
\hline & HSF-Z & 0.083 & & VF-C & 0.082 \\
\hline \multirow[t]{2}{*}{ ТСРP } & HSF-R & 0.201 & & VF-Z & 0.374 \\
\hline & HSF-Z & 0.289 & DEHP & VF-R & 0.751 \\
\hline \multirow[t]{8}{*}{ CAF } & HSF-R & 0.027 & & VF-C & 0.634 \\
\hline & HSF-Z & 0.276 & & VF-Z & 0.751 \\
\hline & & & ТСРР & VF-R & 0.454 \\
\hline & & & & VF-C & 0.379 \\
\hline & & & & VF-Z & 0.331 \\
\hline & & & $\mathrm{CAF}$ & VF-R & 0.076 \\
\hline & & & & VF-C & 0.516 \\
\hline & & & & VF-Z & 0.119 \\
\hline
\end{tabular}




\subsection{Performance Statistics of VF-CW Pilot-Scale Units}

The removal efficiencies of the VF-CW units are presented in Figure $3 b$, and the temporal variation of the EP concentrations in the influent and effluent of VF-CW units throughout the study period is presented in Figure 5. In the VF-CW units, the DEP influent concentration ranged from 0.091 to $3.044 \mu \mathrm{g} / \mathrm{L}$ (Table 3), and for all VF units and the whole monitoring period, the effluent concentrations were lower than the influent values (Figure 5a). The DEP effluent concentrations were below LOD at frequencies $55 \%$, $73 \%$ and $70 \%$ for units VF-R, VF-C and VF-Z, respectively (Table 3). The DEP effluent mean concentration values for the VF-R, VF-C and VF-Z units were $0.058,0.025$ and 0.012 , respectively, while the respective mean removals were $91.1 \%, 98.6 \%$ and $95.4 \%$ (Figure $3 b$ ). There were no statistically significant differences $(p>0.05)$ in percent removals between the VF pilot-scale units (Table 4).

Similar to the HSF-CW units, the VF-C unit demonstrated better overall performance than the VF-R unit, likely due to the more vigorous root system of cattails, something that may lead to increased uptake of DEP. The results also indicate higher removal of DEP in VF-CWs than HSF-CWs. Xiaoyan et al. [6] also reported similar results, where the VF-CWs achieved higher removal (58-83\%) than the HSF-CW units (44-51\%), which was attributed to the fact that aerobic biodegradation is considered a major removal process for PEs in constructed wetlands.

DIBP effluent concentrations, in most cases, were lower than the influent values for all VF-CW units (Figure 5 b). These were below LOQ at frequencies $7 \%$ and $60 \%$ for units VF-C and VF-Z, respectively (Table 3). The influent mean value for the VF-CW units was $0.710 \mu \mathrm{g} / \mathrm{L}$, and the effluent mean values for the VF-R, VF-C and VF-Z units were 0.289, 0.048 and $0.106 \mu \mathrm{g} / \mathrm{L}$, respectively (Table 3 ), while the respective mean removal rates of DIBP were $67.7 \%, 87.8 \%$ and $91.2 \%$ (Figure $3 b$ ). The VF-R unit presented the worst performance, while the overall performance of VF-C and VF-Z units was satisfactory. The statistical analysis (Table 4$)$ indicated statistically significant differences $(p<0.05)$ in percent removals of DIBP between the VF pilot-scale units. The performance of the VF-R unit was statistically lower $(p<0.05)$ than that of the unplanted unit VF-Z (Table 4; MW U-test). These results indicate that DIBP removal by plant uptake in the CW units is negligible, which is in agreement with Li et al. [76], who studied the dibutyl phthalate removal in VF-CW and pointed out negligible plant uptake, photodegradation, volatilization and adsorption on porous media of DIBP, while biodegradation is the primary process for its removal. In VF-CWs, plant uptake photodegradation and volatilization can be considered negligible, and therefore, biodegradation is likely to be the main mechanism in removing DIBP.

As in the case of HSF units, the DNOP effluent concentrations of VF-CW units were lower than influent values for all VF-CW pilot-scale units, and they were also below the LOD at frequencies $50 \%, 47 \%$ and $50 \%$ for VF-R, VF-C and VF-Z units, respectively (Table 3 ; Figure 5c). The influent mean concentration value for the VF-CW units was $0.412 \mu \mathrm{g} / \mathrm{L}$, and the effluent mean concentration values for the VF-R, VF-C and VF-Z units were $0.045,0.016$ and $0.015 \mu \mathrm{g} / \mathrm{L}$, respectively, while the respective mean DNOP removal rates were $91.0 \%$, $92.0 \%$ and $95.2 \%$ (Figure $3 b$ ). No statistically significant differences $(p>0.05)$ in percent removals between the VF-CW units were found (Table 4). In most cases, DEHP effluent concentrations were lower than the influent values for all VF-CW units (Figure 5d). The influent mean concentration value for the VF-CW units was $1.334 \mu \mathrm{g} / \mathrm{L}$, and the effluent mean concentration values were $0.431,0.060$ and $0.181 \mu \mathrm{g} / \mathrm{L}$ for VF-R, VF-C and VF-Z units, respectively, while the respective mean DEHP removal rates were $76.2 \%, 92.0 \%$ and $88.6 \%$ (Figure $3 b$ ). Statistical analysis (Table 4 ) indicated statistically significant differences $(p<0.001)$ in percent removal between the VF-CWs. The DEHP removal efficiency in VF-R was statistically significantly lower than those of VF-C $(p<0.05)$ and VF-Z $(p<0.05)$, and there was no other statistically significant difference (Table 4; MW U-test). The removals of DNOP and DEHP in the present study were found to be higher than the values reported by Xiaoyan et al. [6], where the removals of DNOP and DEHP in pilot-scale VF-CWs were $42-45 \%$ and $45-49 \%$, respectively, using a non-selective detection (GC-FID). 

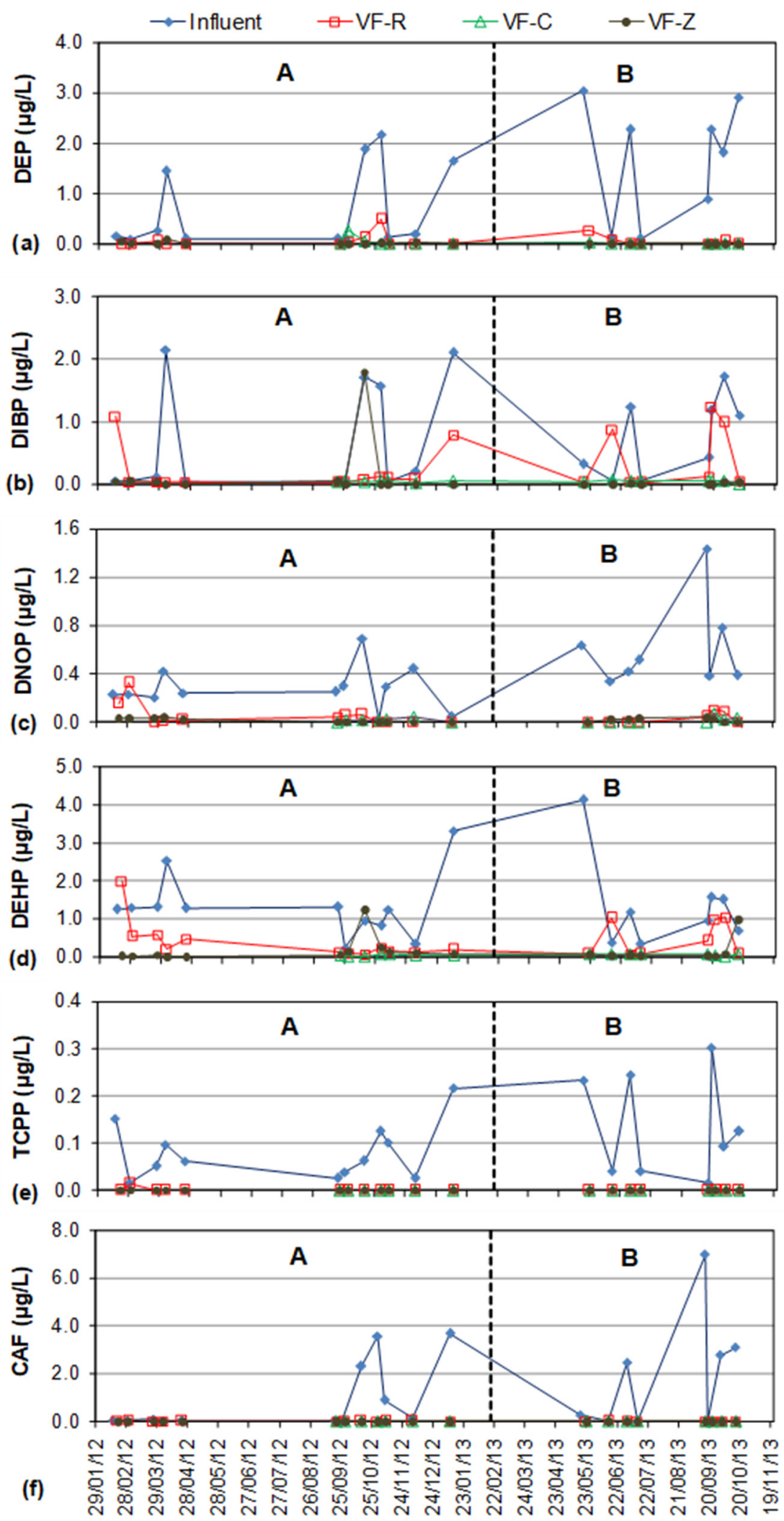

Figure 5. Time series of influent and effluent concentration values in each VF-CW unit for: (a) DEP; (b) DIBP; (c) DNOP; (d) DEHP; (e) TCPP; (f) CAF. Feeding strategies (A: $0.209 \mathrm{~m} / \mathrm{d}$ and B: $0.283 \mathrm{~m} / \mathrm{d}$ ) are also indicated. 
Regarding TCPP and CAF, the influent concentrations were higher than the effluent values throughout the experimental period for all VF-CW units; they were below the LOD at frequencies higher than 95\% for TCPP (Table 3; Figure 5e), and for CAF, they were below the LOQ at frequencies 50\%, 60\% and 90\% for VF-R, VF-C and VF-Z units, respectively (Table 3). The mean removal rates of TCPP were $99.1 \%, 99.0 \%$ and $99.0 \%$, and of CAF 85.3\%, 92.9\% and 95.3\%, for VF-R, VF-C and VF-Z pilot-scale CWs, respectively (Figure 3b). Table 4 (KW test) indicates there were no statistically significant differences in percent removal $(p>0.05)$ between the VF-CW units for both TCPP and CAF. The results show that VF-CWs can remove caffeine at high rates. Similar results with removal efficiencies of $99 \%$ and $82-99 \%$ were reported by Matamoros et al. $[77,78]$.

The mean removal capacities in VF-CW units for both feeding strategies A and B are presented in Table 5. Regarding the mean removal of DEP and DEHP in the VF-R and VF-C units, the removal efficiency was greater for the lower HLR (strategy A). These results agree with the study by Li et al. [76], who found that DIBP removal was higher at a HLR of $0.11 \mathrm{~m} / \mathrm{d}$ than that of $0.33 \mathrm{~m} / \mathrm{d}$. However, statistically significant differences (Table 6; MW U-test: $p<0.05$ ) in the removal capacity between the two feeding strategies (i.e., A and B) were only found for DEP in the VF-Z unit. Therefore, the feeding strategy of the VF-CWs in the present study does not affect the removal of the studied EPs. Matamoros et al. [78] investigated the removal efficiencies of CAF in a VF-CW system at different HLRs (0.013, $0.030,0.070$ and $0.160 \mathrm{~m} / \mathrm{d}$ ) and also found that CAF removal was slightly affected by the loading rate. However, Xiaoyan et al. [6] reported that HLRs play an important role in PE removal in pilot-scale VF-CWs, and PE removal efficiency decreases as the HLR increases.

\subsection{CW Configuration Comparison and Possible Treatment Mechanisms}

The mitigation/elimination and average overall removal of PEs (i.e., DEP, DIBP, DNOP and DEHP) is lower in HSF-CW units than that of VF-CW units (Table 5), indicating that the more oxidizing environment of VF-CWs favors the PEs' microbial degradation [66,79]. In VF-CWs, the presence of the aeration tubes and intermittent feeding allowing for a resting period enhance the transfer of oxygen to the media, boosting PE removal. Xiaoyan et al. [6] reported that VF-CWs showed better performance than HSF-CWs for DEP, DIBP, DNOP and DEHP. Previous studies showed that microorganisms play a major role in PE degradation under aerobic and anaerobic conditions $[6,76,80]$. Furthermore, the length of the alkyl side chains and the alkyl branch chains, as well as the molecular weight, affects the biodegradability of the PEs [13]. PEs with lower molecular weight and short alkyl chains are more easily degraded than PEs with higher molecular weight and long alkyl chains. Thus, the DEP reduction was higher than that of DEHP in the VF pilot-scale units.

Additionally, these compounds can be removed in the CW environment by various mechanisms, such as plant uptake, sedimentation and/or adsorption on porous media. Compounds with $\mathrm{LogK}_{\mathrm{ow}}$ values ranging from 3.0 to 4.0 are more easily transported and accumulated in plant tissues with optimum root uptake and translocation to shoots for LogK $\mathrm{K}_{\mathrm{ow}}$ values 1 to 3 [81]. Therefore, high phytoaccumulation of DEP is expected because of its $\operatorname{LogK}_{\mathrm{ow}}$ value of 2.47 (Table 1). The results showed that the removal of DEP in the planted HSF-CWs was higher than that in the unplanted unit, and the removal in HSF-C unit (planted with cattail) was statistically significantly higher than that of the unplanted HSF-Z CW (Table 4; Figure 3a). Table 4 also shows that, for the remaining PEs studied, no significantly different removals between the planted and unplanted units were observed. This means that the contribution of plants to the removal of these compounds is negligible. On the other hand, many studies have reported that as $\mathrm{LogK}_{\mathrm{ow}}$ increases, there is a greater tendency for PEs to adsorb on substate or accumulate in plants $[6,13,69,80]$. DIBP, DNOP and DEHP have low water solubility and $\operatorname{LogK}_{\mathrm{ow}}>4$, and, therefore, high adsorption of them on substrate is expected. Specifically, DEHP plant uptake by Typha species was reported by Diepenheim et al. [71]. TCPP and CAF are not affected by direct photodegradation $[15,28]$. TCPP has a low octanol-water coefficient $\left(\operatorname{LogK}_{\mathrm{ow}}=2.59\right)$ and low biodegradability. According to Zhang et al. [56], plant uptake plays the dominant 
role in CAF elimination, due to its high polarity and water solubility (Table 1), while biodegradation only plays a minor role.

\section{Conclusions}

Three HSF and three VF pilot-scale CWs with different configurations were shown to be a reliable and efficient technology for emerging pollutant (EP) removal from domestic wastewater originating in a university campus. HSF-CW units showed relatively low removal capabilities for DIBP and DEHP, with an overall average removal of $76.7 \%$ and $70.7 \%$, respectively. The highest phthalate ester (PE) removal was seen in the VF-CWs (81.894.6\%), although in HSF-CWs, PE removal efficiency (70.7-90.9\%) was quite satisfying. The results of the present study indicate that for HSF-CW units, an HRT of 14 days may be adequate for target compound removal, and the loading rate of the VF-CWs does not play an important role in the removal of the EPs studied. Biodegradation under aerobic and/or anaerobic conditions and adsorption on the substrate are the main removal mechanisms of the target EPs, while the presence of plants has little impact on their removal in CWs. This research highlights the overall efficacy of HSF and VF-CWs in EP removal, and indicates that CWs may be a useful technology in removing EPs from municipal wastewaters.

Author Contributions: Conceptualization, V.A.T. and G.D.G.; methodology, V.A.T., G.D.G. and I.K.K.; investigation, G.D.G., V.A.P., I.K.K. and M.A.; writing—original draft preparation, G.D.G. and V.A.P.; writing-review and editing, V.A.T., I.K.K. and M.A.; supervision, V.A.T. All authors have read and agreed to the published version of the manuscript.

Funding: No funding received.

Institutional Review Board Statement: Not applicable.

Informed Consent Statement: Not applicable.

Data Availability Statement: The data supporting the research findings of this study are available from the corresponding author upon request.

Conflicts of Interest: The authors declare no conflict of interest.

\section{References}

1. EU. Directive 2013/39/EU of the European Parliament and of the Council of 12 August 2013 Amending Directives 2000/60/EC and 2008/105/EC as Regards Priority Substances in the Field of Water Policy. Official Journal of the European Union. 2013. Available online: https:/ / eur-lex.europa.eu/legal-content/EN/ALL/?uri=CELEX\%3A32013L0039 (accessed on 20 July 2021).

2. EC. Commission Regulation No $2364 / 2000$ of 25 October 2000 Concerning the Fourth List of Priority Substances as Foreseen under Council Regulation (EEC) No 793/93. 2000. Available online: http:/ / data.europa.eu/eli/reg/2000/2364/oj (accessed on 20 July 2021).

3. EC. Regulation (EC) No 1272/2008 of the European Parliament and of the Council of 16 December 2008 on Classification, Labelling and Packaging of Substances and Mixtures, Amending and Repealing Directives 67/548/EEC and 1999/45/EC, and Amending Regulation (EC) No 1907/2006. 2008. Available online: https:/ / eur-lex.europa.eu/LexUriServ/LexUriServ.do?uri=OJ: L:2008:353:0001:1355:en:PDF (accessed on 20 July 2021).

4. Li, B.; Liu, R.; Gao, H.; Tan, R.; Zeng, P.; Song, Y. Spatial distribution and ecological risk assessment of phthalic acid esters and phenols in surface sediment from urban rivers in Northeast China. Environ. Pollut. 2016, 219, 409-415. [CrossRef] [PubMed]

5. Stamatis, N.K.; Konstantinou, I.K. Occurrence and removal of emerging pharmaceutical, personal care compounds and caffeine tracer in municipal sewage treatment plant in Western Greece. J. Environ. Sci. Health Part B 2013, 48, 800-813. [CrossRef] [PubMed]

6. Xiaoyan, T.; Suyu, W.; Yang, Y.; Ran, T.; Yunv, D.; Dan, A.; Li, L. Removal of six phthalic acid esters (PAEs) from domestic sewage by constructed wetlands. Chem. Eng. J. 2015, 275, 198-205. [CrossRef]

7. Antonopoulou, M.; Giannakas, A.; Bairamis, F.; Papadaki, M.; Konstantinou, I. Degradation of organophosphorus flame retardant tris(1-chloro-2-propyl) phosphate (TCPP) by visible light N,S-codoped TiO 2 photocatalysts. Chem. Eng. J. 2017, 318, 231-239. [CrossRef]

8. Sayyad, G.; Price, G.; Sharifi, M.; Khosravi, K. Fate and transport modeling of phthalate esters from biosolid amended soil under corn cultivation. J. Hazard. Mater. 2017, 323, 264-273. [CrossRef] [PubMed]

9. Birkett, J.A.; Lester, J.N. Endocrine Disruptors in Wastewater and Sludge Treatment Processes; CRC Press LLC: Boca Raton, FL, USA, 2003. 
10. Bui, T.T.; Giovanoulis, G.; Cousins, A.P.; Magnér, J.; Cousins, I.T.; de Wit, C.A. Human exposure, hazard and risk of alterna-tive plasticizers to phthalate esters. Sci. Total Environ. 2016, 541, 451-467. [CrossRef]

11. Golfinopoulos, S.K.; Nikolaou, A.D.; Thomaidis, N.S.; Kotrikla, A.M.; Vagi, M.C.; Petsas, A.S.; Lekkas, D.F.; Lekkas, T.D. Determination of the priority substances regulated by 2000/60/EC and 2008/105/EC Directives in the surface waters supplying water treatment plants of Athens, Greece. J. Environ. Sci. Health Part A 2016, 52, 378-384. [CrossRef]

12. Martí, N.; Aguado, D.; Segovia-Martínez, L.; Bouzas, A.; Seco, A. Occurrence of priority pollutants in WWTP effluents and Mediterranean coastal waters of Spain. Mar. Pollut. Bull. 2011, 62, 615-625. [CrossRef]

13. Gao, D.-W.; Wen, Z.-D. Phthalate esters in the environment: A critical review of their occurrence, biodegradation, and removal during wastewater treatment processes. Sci. Total Environ. 2016, 541, 986-1001. [CrossRef]

14. Van der Veen, I.; de Boer, J. Phosphorus flame retardants: Properties, production, environmental occurrence, toxicity and analysis. Chemosphere 2012, 88, 1119-1153. [CrossRef]

15. Regnery, J.; Püttmann, W. Occurrence and fate of organophosphorus flame retardants and plasticizers in urban and remote surface waters in Germany. Water Res. 2010, 44, 4097-4104. [CrossRef]

16. Schreder, E.D.; La Guardia, M. Flame Retardant Transfers from U.S. Households (Dust and Laundry Wastewater) to the Aquatic Environment. Environ. Sci. Technol. 2014, 48, 11575-11583. [CrossRef]

17. Antonopoulou, M.; Karagianni, P.; Konstantinou, I. Kinetic and mechanistic study of photocatalytic degradation of flame retardant Tris (1-chloro-2-propyl) phosphate (TCPP). Appl. Catal. B Environ. 2016, 192, 152-160. [CrossRef]

18. Reemtsma, T.; Quintana, J.B.; Rodil, R.; García-López, M.; Rodríguez, I. Organophosphorus flame retardants and plasticizers in water and air I. Occurrence and fate. TrAC Trends Anal. Chem. 2008, 27, 727-737. [CrossRef]

19. Marklund, A.; Andersson, A.B.; Haglund, P. Organophosphorus Flame Retardants and Plasticizers in Swedish Sewage Treatment Plants. Environ. Sci. Technol. 2005, 39, 7423-7429. [CrossRef]

20. EU. Directive 2014/79/EU of 20 June 2014 amending Appendix C of Annex II to Directive 2009/48/EC of the European Parliament and of the Council on the Safety of Toys, as Regards TCEP, TCPP and TDCP Text with EEA Relevance. 2014. Available online: http:/ / data.europa.eu/eli/dir/2014/79/oj (accessed on 20 July 2021).

21. Lee, S.; Jeong, W.; Kannan, K.; Moon, H.-B. Occurrence and exposure assessment of organophosphate flame retardants (OPFRs) through the consumption of drinking water in Korea. Water Res. 2016, 103, 182-188. [CrossRef] [PubMed]

22. Loos, R.; Carvalho, R.; António, D.C.; Comero, S.; Locoro, G.; Tavazzi, S.; Paracchini, B.; Ghiani, M.; Lettieri, T.; Blaha, L.; et al. EU-wide monitoring survey on emerging polar organic contaminants in wastewater treatment plant effluents. Water Res. 2013, 47, 6475-6487. [CrossRef] [PubMed]

23. Wolschke, H.; Sühring, R.; Xie, Z.; Ebinghaus, R. Organophosphorus flame retardants and plasticizers in the aquatic environment: A case study of the Elbe River, Germany. Environ. Pollut. 2015, 206, 488-493. [CrossRef]

24. Bollmann, U.E.; Möller, A.; Xie, Z.; Ebinghaus, R.; Einax, J.W. Occurrence and fate of organophosphorus flame retardants and plasticizers in coastal and marine surface waters. Water Res. 2012, 46, 531-538. [CrossRef]

25. Cristale, J.; Katsoyiannis, A.; Sweetman, A.; Jones, K.C.; Lacorte, S. Occurrence and risk assessment of organophosphorus and brominated flame retardants in the River Aire (UK). Environ. Pollut. 2013, 179, 194-200. [CrossRef] [PubMed]

26. Blum, K.M.; Andersson, P.L.; Renman, G.; Ahrens, L.; Gros, M.; Wiberg, K.; Haglund, P. Non-target screening and prioritization of potentially persistent, bioaccumulating and toxic domestic wastewater contaminants and their removal in on-site and large-scale sewage treatment plants. Sci. Total Environ. 2017, 575, 265-275. [CrossRef]

27. Zolfaghari, M.; Drogui, P.; Seyhi, B.; Brar, S.; Buelna, G.; Dubé, R. Occurrence, fate and effects of Di(2-ethylhexyl) phthalate in wastewater treatment plants: A review. Environ. Pollut. 2014, 194, 281-293. [CrossRef]

28. Zhang, D.Q.; Hua, T.; Gersberg, R.M.; Zhu, J.; Ng, W.J.; Tan, S.K. Fate of caffeine in mesocosms wetland planted with Scirpus validus. Chemosphere 2013, 90, 1568-1572. [CrossRef]

29. Vymazal, J.; Březinová, T.D.; Koželuh, M.; Kule, L. Occurrence and removal of pharmaceuticals in four full-scale constructed wetlands in the Czech Republic-The first year of monitoring. Ecol. Eng. 2017, 98, 354-364. [CrossRef]

30. Papageorgiou, M.; Kosma, C.; Lambropoulou, D. Seasonal occurrence, removal, mass loading and environmental risk assessment of 55 pharmaceuticals and personal care products in a municipal wastewater treatment plant in Central Greece. Sci. Total Environ. 2016, 543, 547-569. [CrossRef] [PubMed]

31. Chen, Y.; Vymazal, J.; Březinová, T.; Koželuh, M.; Kule, L.; Huang, J.; Chen, Z. Occurrence, removal and environmental risk assessment of pharmaceuticals and personal care products in rural wastewater treatment wetlands. Sci. Total Environ. 2016, 566-567, 1660-1669. [CrossRef] [PubMed]

32. Kosma, C.I.; Lambropoulou, D.A.; Albanis, T.A. Investigation of PPCPs in wastewater treatment plants in Greece: Occurrence, removal and environmental risk assessment. Sci. Total Environ. 2014, 466-467, 421-438. [CrossRef]

33. Lämmchen, V.; Klasmeier, J.; Hernandez-Leal, L.; Berlekamp, J. Spatial Modelling of Micro-pollutants in a Strongly Regulated Cross-border Lowland Catchment. Environ. Process. 2021, 8, 973-992. [CrossRef]

34. Tiehm, A.; Schmidt, N.; Stieber, M.; Sacher, F.; Wolf, L.; Hoetzl, H. Biodegradation of Pharmaceutical Compounds and their Occurrence in the Jordan Valley. Water Resour. Manag. 2011, 25, 1195-1203. [CrossRef]

35. Khan, S.; Knapp, C.W.; Beattie, T.K. Antibiotic Resistant Bacteria Found in Municipal Drinking Water. Environ. Process. 2016, 3 , 541-552. [CrossRef] 
36. Fast, S.A.; Gude, V.G.; Truax, D.D.; Martin, J.; Magbanua, B.S. A Critical Evaluation of Advanced Oxidation Processes for Emerging Contaminants Removal. Environ. Process. 2017, 4, 283-302. [CrossRef]

37. Castañer, C.M.; Bellver-Domingo, Á.; Hernández-Sancho, F. Environmental and Economic Approach to Assess a Horizontal Sub-Surface Flow Wetland in Developing Area. Water Resour. Manag. 2020, 34, 3761-3778. [CrossRef]

38. Yuan, Z.; Fu, S.; Xu, X.; Wendling, L.A. Mineral Processing Residue Use as Substrate in a Modular Engineered Wetland for Wastewater Treatment. Environ. Process. 2017, 4, 523-547. [CrossRef]

39. Gkika, D.; Gikas, G.D.; Tsihrintzis, V.A. Construction and operation costs of constructed wetlands treating wastewater. Water Sci. Technol. 2014, 70, 803-810. [CrossRef]

40. Srđević, Z.; Srđević, B.; Suvočarev, K.; Galamboš, L. Hybrid Constructed Wetland Selection as a Group Decision-Making Problem. Water Resour. Manag. 2019, 34, 295-310. [CrossRef]

41. Koenig, S.; Trémolières, M. Transfer of Nitrogen and Phosphorus Nutrients in Vegetated Buffer Zones Receiving Treatment Plant Effluent. Environ. Process. 2018, 5, 555-575. [CrossRef]

42. Angassa, K.; Leta, S.; Mulat, W.; Kloos, H.; Meers, E. Organic Matter and Nutrient Removal Performance of Horizontal Subsurface Flow Constructed Wetlands Planted with Phragmite karka and Vetiveria zizanioide for Treating Municipal Wastewater. Environ. Process. 2018, 5, 115-130. [CrossRef]

43. Angassa, K.; Leta, S.; Mulat, W.; Kloos, H.; Meers, E. Evaluation of Pilot-Scale Constructed Wetlands with Phragmites karka for Phytoremediation of Municipal Wastewater and Biomass Production in Ethiopia. Environ. Process. 2019, 6, 65-84. [CrossRef]

44. Kotti, I.P.; Sylaios, G.K.; Tsihrintzis, V.A. Fuzzy Modeling for Nitrogen and Phosphorus Removal Estimation in Free-Water Surface Constructed Wetlands. Environ. Process. 2016, 3, 65-79. [CrossRef]

45. Papadopoulos, N.; Zalidis, G. The Use of Typha Latifolia L. in Constructed Wetland Microcosms for the Remediation of Herbicide Terbuthylazine. Environ. Process. 2019, 6, 985-1003. [CrossRef]

46. Ioannidou, V.G.; Pearson, J.M. Hydraulic and Design Parameters in Full-Scale Constructed Wetlands and Treatment Units: Six Case Studies. Environ. Process. 2018, 5, 5-22. [CrossRef]

47. Alemu, T.; Lemma, E.; Mekonnen, A.; Leta, S. Performance of Pilot Scale Anaerobic-SBR System Integrated with Constructed Wetlands for the Treatment of Tannery Wastewater. Environ. Process. 2016, 3, 815-827. [CrossRef]

48. Reyes-Contreras, C.; Matamoros, V.; Ruiz, I.; Soto, M.; Bayona, J. Evaluation of PPCPs removal in a combined anaerobic digester-constructed wetland pilot plant treating urban wastewater. Chemosphere 2011, 84, 1200-1207. [CrossRef] [PubMed]

49. Herrera-Cárdenas, J.; Navarro, A.E.; Torres, E. Effects of porous media, macrophyte type and hydraulic retention time on the removal of organic load and micropollutants in constructed wetlands. J. Environ. Sci. Health Part A 2016, 51, 380-388. [CrossRef]

50. Noutsopoulos, C.; Charalambous, V.; Koumaki, E. Evaluating the Fate of Emerging Contaminants in Wastewater Treatment Plants through Plant-Wide Mathematical Modelling. Environ. Process. 2020, 7, 1065-1094. [CrossRef]

51. Matamoros, V.; Salvadó, V. Evaluation of the seasonal performance of a water reclamation pond-constructed wetland system for removing emerging contaminants. Chemosphere 2012, 86, 111-117. [CrossRef]

52. Li, B.; Liu, L.; Han, L.; Yang, Y. Removal efficiency of polycyclic aromatic hydrocarbons and phthalate esters by surface flow wetland in Shunyi district, Beijing. IOP Conf. Ser. Earth Environ. Sci. 2017, 59, 12041. [CrossRef]

53. Hassanzadeh, N.; Sari, A.E.; Khodabandeh, S.; Bahramifar, N. Occurrence and distribution of two phthalate esters in the sediments of the Anzali wetlands on the coast of the Caspian Sea (Iran). Mar. Pollut. Bull. 2014, 89, 128-135. [CrossRef]

54. Sun, J.; Ji, X.; Zhang, R.; Huang, Y.; Liang, Y.; Du, J.; Xie, X.; Li, A. Endocrine disrupting compounds reduction and water quality improvement in reclaimed municipal wastewater: A field-scale study along Jialu River in North China. Chemosphere 2016, 157, 232-240. [CrossRef] [PubMed]

55. Yang, C.-F.; Wang, C.-C.; Chen, C.-H. Di-n-butyl phthalate removal by strain Deinococcus sp. R5 in batch reactors. Int. Biodeterior Biodegrad. 2014, 95, 55-60. [CrossRef]

56. Zhang, D.; Gersberg, R.M.; Ng, W.J.; Tan, S.K. Removal of pharmaceuticals and personal care products in aquatic plant-based systems: A review. Environ. Pollut. 2014, 184, 620-639. [CrossRef] [PubMed]

57. Wen, Z.-D.; Wu, W.; Ren, N.-Q.; Gao, D.-W. Synergistic effect using vermiculite as media with a bacterial biofilm of Arthrobacter sp. for biodegradation of di-(2-ethylhexyl) phthalate. J. Hazard. Mater. 2016, 304, 118-125. [CrossRef]

58. Akratos, C.; Tsihrintzis, V.A. Effect of temperature, HRT, vegetation and porous media on removal efficiency of pilot-scale horizontal subsurface flow constructed wetlands. Ecol. Eng. 2007, 29, 173-191. [CrossRef]

59. Stefanakis, A.I.; Tsihrintzis, V.A. Performance of pilot-scale vertical flow constructed wetlands treating simulated municipal wastewater: Effect of various design parameters. Desalination 2009, 248, 753-770. [CrossRef]

60. Stefanakis, A.; Tsihrintzis, V.A. Effects of loading, resting period, temperature, porous media, vegetation and aeration on performance of pilot-scale vertical flow constructed wetlands. Chem. Eng. J. 2012, 181-182, 416-430. [CrossRef]

61. Papaevangelou, V.A.; Gikas, G.D.; Tsihrintzis, V.A. Evaluation of evapotranspiration in small on-site HSF constructed wetlands. J. Environ. Sci. Health Part A 2012, 47, 766-785. [CrossRef]

62. Papaevangelou, V.; Gikas, G.D.; Tsihrintzis, V.A. Effect of operational and design parameters on performance of pilot-scale horizontal subsurface flow constructed wetlands treating university campus wastewater. Environ. Sci. Pollut. Res. 2016, 23, 19504-19519. [CrossRef] 
63. Papaevangelou, V.; Gikas, G.D.; Tsihrintzis, V.A. Effect of Operational and Design Parameters on Performance of Pilot-Scale Vertical Flow Constructed Wetlands Treating University Campus Wastewater. Water Resour. Manag. 2016, 30, 5875-5899. [CrossRef]

64. PubChem. National Library of Medicine, National Center for Biotechnology Information. 2021. Available online: https: / / pubchem.ncbi.nlm.nih.gov/ (accessed on 20 July 2021).

65. Papaevangelou, V.A.; Gikas, G.D.; Tsihrintzis, V.A.; Antonopoulou, M.; Konstantinou, I.K. Removal of Endocrine Disrupting Chemicals in HSF and VF pilot-scale constructed wetlands. Chem. Eng. J. 2016, 294, 146-156. [CrossRef]

66. Kadlec, R.H.; Wallace, S.D. Treatment Wetlands, 2nd ed.; CRC Press: Boca Raton, FL, USA, 2009.

67. Gikas, G.D.; Vryzas, Z.; Tsihrintzis, V.A. S-metolachlor herbicide removal in pilot-scale horizontal subsurface flow constructed wetlands. Chem. Eng. J. 2018, 339, 108-116. [CrossRef]

68. Verlicchi, P.; Zambello, E. How efficient are constructed wetlands in removing pharmaceuticals from untreated and treated urban wastewaters? A review. Sci. Total Environ. 2014, 470-471, 1281-1306. [CrossRef] [PubMed]

69. Zheng, L.; Liu, T.; Xie, E.; Liu, M.; Ding, A.; Zhang, B.-T.; Li, X.; Zhang, D. Partition and Fate of Phthalate Acid Esters (PAEs) in a Full-Scale Horizontal Subsurface Flow Constructed Wetland Treating Polluted River Water. Water 2020, 12, 865. [CrossRef]

70. Clara, M.; Windhofer, G.; Hartl, W.; Braun, K.; Simon, M.; Gans, O.; Scheffknecht, C.; Chovanec, A. Occurrence of phthalates in surface runoff, untreated and treated wastewater and fate during wastewater treatment. Chemosphere 2010, 78, 1078-1084. [CrossRef]

71. Diepenheim, G.; Gift, S.C.; Harb, C.; Wallace, M.; Layshock, J. Survey of Phthalate Mitigation and Distribution in Water, Sediment, and Typha in a Fully Operational Constructed Wetland: A Pilot Study. Bull. Environ. Contam. Toxicol. 2020, 105, 205-210. [CrossRef]

72. Iqbal, M.; Syed, J.H.; Katsoyiannis, A.; Malik, R.N.; Farooqi, A.; Butt, A.; Li, J.; Zhang, G.; Cincinelli, A.; Jones, K.C. Legacy and emerging flame retardants (FRs) in the freshwater ecosystem: A review. Environ. Res. 2017, 152, 26-42. [CrossRef] [PubMed]

73. Qin, P.; Lu, S.; Liu, X.; Wang, G.; Zhang, Y.; Li, D.; Wan, Z. Removal of tri-(2-chloroisopropyl) phosphate (TCPP) by three types of constructed wetlands. Sci. Total Environ. 2020, 749, 141668. [CrossRef] [PubMed]

74. Brunsch, A.F.; ter Laak, T.L.; Christoffels, E.; Rijnaarts, H.H.; Langenhoff, A.A. Retention soil filter as post-treatment step to remove micropollutants from sewage treatment plant effluent. Sci. Total Environ. 2018, 637-638, 1098-1107. [CrossRef]

75. Li, Y.; Zhu, G.; Ng, W.J.; Tan, S.K. A review on removing pharmaceutical contaminants from wastewater by constructed wetlands: Design, performance and mechanism. Sci. Total Environ. 2014, 468-469, 908-932. [CrossRef] [PubMed]

76. Li, T.; Fan, Y.; Cun, D.; Song, X.; Dai, Y.; Wang, F.; Wu, C.; Liang, W. Treatment performance and microbial response to dibutyl phthalate contaminated wastewater in vertical flow constructed wetland mesocosms. Chemosphere 2020, 246, 125635. [CrossRef]

77. Matamoros, V.; Arias, C.A.; Brix, H.; Bayona, J.M. Preliminary screening of small-scale domestic wastewater treatment systems for removal of pharmaceutical and personal care products. Water Res. 2009, 43, 55-62. [CrossRef] [PubMed]

78. Matamoros, V.; Arias, C.A.; Brix, H.; Bayona, J.M. Removal of Pharmaceuticals and Personal Care Products (PPCPs) from Urban Wastewater in a Pilot Vertical Flow Constructed Wetland and a Sand Filter. Environ. Sci. Technol. 2007, 41, 8171-8177. [CrossRef] [PubMed]

79. Ávila, C.; Nivala, J.; Olsson, L.; Kassa, K.; Headley, T.; Mueller, R.A.; Bayona, J.M.; García, J. Emerging organic contaminants in vertical subsurface flow constructed wetlands: Influence of media size, loading frequency and use of active aeration. Sci. Total Environ. 2014, 494-495, 211-217. [CrossRef] [PubMed]

80. Witthayaphirom, C.; Chiemchaisri, C.; Chiemchaisri, W.; Ogata, Y.; Ebie, Y.; Ishigaki, T. Organic micro-pollutant removals from landfill leachate in horizontal subsurface flow constructed wetland operated in the tropical climate. J. Water Process. Eng. 2020, 38 , 101581. [CrossRef]

81. Guo, W.; Zhang, H.; Huo, S. Organochlorine pesticides in aquatic hydrophyte tissues and surrounding sediments in Baiyang-dian wetland, China. Ecol. Eng. 2014, 67, 150-155. [CrossRef] 